\title{
Berries grown in Brazil: anthocyanin profiles and biological properties
}

\author{
Vitor C Chaves, ${ }^{\mathrm{a}, \mathrm{b}} \odot$ Laurita Boff, $^{\mathrm{a}}$ Márcia Vizzotto, ${ }^{\mathrm{c}}$ Eunice Calvete, ${ }^{\mathrm{d}}$ \\ Flávio H Reginatto ${ }^{b}$ and Cláudia MO Simões ${ }^{a, b^{*}}$
}

\begin{abstract}
BACKGROUND: Phytochemical profiles of two Brazilian native fruits - pitanga (red and purple) and araçá (yellow and red) - as well as strawberry cultivars Albion, Aromas and Camarosa, blackberry cultivar Tupy and blueberry cultivar Bluegen cultivated in Brazil were characterized for total phenolic content and total anthocyanin content by liquid chromatography coupled to a photodiode array and a quadrupole time-of-flight mass spectrometer. Radical scavenging, antiherpes and cytotoxic activities of these berry extracts were also evaluated.

RESULTS: Blueberry presented the highest total anthocyanin content (1202 $\mathrm{mg}$ cyanidin-O-glucoside equivalents $\mathrm{kg}^{-1}$ fresh $^{-}$

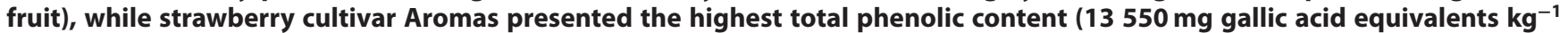
fresh fruit). Liquid chromatographic-mass spectrometric analysis resulted in the identification of 21 anthocyanins. To the best of our knowledge this is the first report of cyanidin-O-glucoside in yellow and red Araçá fruit and the first time eight anthocyanins have been reported in pitanga fruits. DPPH and ABTS assays showed that blueberry cultivar Bluegen, blackberry cultivar Tupy and pitanga (red and purple) showed the most promising antiradical activities, respectively. No relevant cytotoxicity against three cancer cell lines or antiherpes activity was detected under the experimental conditions tested.
\end{abstract}

CONCLUSION: Total anthocyanin content of all fruits had a strong positive correlation with their free radical scavenging activity, suggesting anthocyanins contribute to the antioxidant potential of these fruits.

(c) 2018 Society of Chemical Industry

Keywords: berries; anthocyanins; LC/PDA/Q-TOF-MS; Eugenia uniflora; Psidium cattleianum

\section{INTRODUCTION}

Berries constitute a large group of functional foods whose consumption has demonstrated a broad spectrum of positive effects in human health, including those in cardiovascular disorders, inflammatory conditions, metabolic syndrome, as well as distinct degenerative diseases. These effects have been related to specific phytochemicals, mainly phenolic compounds, such as phenolic acids, tannins and anthocyanins, the major compounds present in berries, which also improve neuronal and cognitive brain functions and protect genomic DNA integrity. ${ }^{1,2}$

Anthocyanins constitute the largest and likely the most important group of water-soluble plant pigments, and are responsible for the blue, purple and red color of diverse tissues. Anthocyanins have a flavilium cation as their core structure, with different sugars attached at position C3. Epidemiological data suggest a direct correlation between anthocyanin intake and low incidence of chronic and degenerative diseases, and anthocyanins also present a promising alternative to synthetic food dyes., ${ }^{3,4}$

Recently, the cultivation of certain berries in Brazil has expanded, especially in subtropical areas, and has been accompanied by an increase in consumption of blueberries (Vaccinium virgatum A.), strawberries (Fragaria $\times$ ananassa Duch.) and blackberries (Rubus sp.), as well as native Brazilian berries such as 'pitanga' (Eugenia uniflora L.) and 'araçá' (Psidium cattleianum S.). ${ }^{5-8}$

The investigation of anthocyanin composition of berries is relevant since it can be influenced by several factors such as geographical location, temperature and cultivation parameters. ${ }^{9}$ Therefore, considering the limited number of investigations related to the chemical content of both Brazilian wild berries cited above, the present study aimed to characterize the anthocyanin profiles of different berries grown in Brazil. In addition, their antioxidant potential, antiherpes effects, as well as their cytotoxicity against human cancer cell lines, were evaluated.

* Correspondence to: CMO Simões, Laboratório de Virologia Aplicada, Programa de Pós-Graduação em Biotecnologia e Biociências, Centro de Ciências Biológicas, Universidade Federal de Santa Catarina, Florianópolis, SC, Brazil. E-mail:claudia.simoes@ufsc.br

a Laboratório de Virologia Aplicada, Programa de Pós-Graduação em Biotecnologia e Biociências, Centro de Ciências Biológicas, Universidade Federal de Santa Catarina, Florianópolis, SC, Brazil

b Laboratório de Farmacognosia, Departamento de Ciências Farmacêuticas, Centro de Ciências da Saúde, Universidade Federal de Santa Catarina, Florianópolis, SC, Brazil

c Empresa Brasileira de Pesquisa Agropecuária de Clima Temperado (EMBRAPA), Pelotas, RS, Brazil

d Programa de Pós-Graduação em Agronomia, Universidade de Passo Fundo, $U P F$, Passo Fundo, RS, Brazil 


\section{MATERIALS AND METHODS}

Plant material

Fruit of red and purple varieties of Eugenia uniflora (pitanga), yellow and red varieties of Psidium cattleianum (araçá), Rubus sp. (blackberry) cultivar Tupy and Vaccinium virgatum (blueberry) cultivar Bluegen were cultivated at Empresa Brasileira de Pesquisa Agropecuária de Clima Temperado (EMBRAPA) in Pelotas, RS, Brazil $\left(31^{\circ} 40^{\prime} 50.6^{\prime \prime} \mathrm{S}, 52^{\circ} 26^{\prime} 23.1^{\prime \prime} \mathrm{W}\right)$. Fragaria $\times$ ananassa (strawberry) cultivars Albion, Aromas and Camarosa were cultivated at the Universidade de Passo Fundo in Passo Fundo, RS, Brazil $\left(28^{\circ} 13^{\prime}\right.$ $\left.58.5^{\prime \prime} \mathrm{S} ; 52^{\circ} 23^{\prime} 00.7^{\prime \prime} \mathrm{W}\right)$. After harvesting, fruits were stored at $-20^{\circ} \mathrm{C}$ until extraction and analyses.

\section{Extraction procedures}

Extracts of all fruits were prepared by sonication (Ultrasonic Cleaner 1450, Unique) using $1 \mathrm{~g}$ frozen fruits milled in an electric blender (LAR4, METVISA ${ }^{\circledR}$, Brazil) and $60 \mathrm{~mL}$ methanol for $50 \mathrm{~min}$ at room temperature $\left(23 \pm 2{ }^{\circ} \mathrm{C}\right)$. The extracts were filtered in qualitative filter paper (particle retention: 4-12 $\mu \mathrm{m}$ ) and concentrated to dryness under reduced pressure yielding the crude extracts. Each extract was then solubilized in distilled water $(30 \mathrm{~mL})$, freeze dried and then lyophilized. All extracts were stored at $-20^{\circ} \mathrm{C}$ for no longer than 60 days prior to phytochemical analyses and biological assays. All extractions were performed in triplicate.

\section{Liquid chromatography-photodiode array detection-quadrupole time-of-flight-mass spectrometry (LC/PDA/Q-TOF-MS) of anthocyanins}

Anthocyanins were individually identified and quantified by ultra-performance liquid chromatography (Acquity-UPLC ${ }^{\mathrm{TM}}$ ) coupled to a photodiode array detector (PDA) and a high-resolution mass spectrometer (Xevo ${ }^{\circledR}$ G2 QTof model, Waters ${ }^{\circledR}$ ) equipped with an electrospray ionization source (ESI) operating in positive mode. The chromatographic separation was performed using a Synergi ${ }^{\mathrm{TM}}$ column (Phenomenex ${ }^{\circledR}$, i.d. $4 \mu \mathrm{m}, 150 \times 2.0 \mathrm{~mm}$ ) at $40^{\circ} \mathrm{C}$ and the injection volume was set at $5 \mu \mathrm{L}$. The elution was performed using an aqueous phase consisting of formic acid $2 \%$ (solvent A) and acetonitrile containing 1\% formic acid (solvent B). A linear gradient according to the following conditions was used: $0-10 \mathrm{~min}, 5-12 \% \mathrm{~B} ; 10-29 \mathrm{~min}, 12-18 \% \mathrm{~B} ; 29-33 \mathrm{~min}$, $18 \% \mathrm{~B} ; 33-34 \mathrm{~min}, 5 \% \mathrm{~B}$ with a constant flow of $0.4 \mathrm{~mL} \mathrm{~min}{ }^{-1}$. The detection was performed at $520 \mathrm{~nm}$, and the range of spectral scanning in the visible region ranged from 450 to $600 \mathrm{~nm}$ (PDA). Mass scanning ranged from $\mathrm{m} / \mathrm{z} 200$ to 1500 with a scan time of $0.5 \mathrm{~s}$. MS/MS analyses were performed using a collision energy ramp $(10-30 \mathrm{eV})$ with argon as the collision gas. The capillary voltage of $1.0 \mathrm{kV}$, source block temperature of $120^{\circ} \mathrm{C}$, desolvation temperature of $600^{\circ} \mathrm{C}$, nebulizer nitrogen flow rate of $80 \mathrm{~L} \mathrm{~h}^{-1}$, desolvation nitrogen gas flow of $800 \mathrm{~L} \mathrm{~h}^{-1}$ and cone voltage of $40 \mathrm{~V}$ were used, controlled by MassLynx v.4.1 software for data acquisition and processing. All samples were analyzed in triplicate; the methodology was validated, and specificity, linearity, accuracy, precision, and detection and quantitation limits were measured.

\section{Total phenolic content (TPC)}

TPC was determined by the Folin-Ciocalteu assay. ${ }^{10}$ Samples and standards were analyzed in triplicate and the results were expressed as milligrams of gallic acid equivalents per gram of fresh fruit (mg GAE g ${ }^{-1} \mathrm{FF}$ ). A gallic acid standard curve was prepared with concentrations ranging from 60 to $300 \mu \mathrm{g} \mathrm{mL}^{-1}\left(R^{2}=0.998\right)$.

\section{Total anthocyanin content (TAC)}

The determination of total monomeric anthocyanin content was performed using the $\mathrm{pH}$ differential method ${ }^{11}$ at two wavelengths (520 and $700 \mathrm{~nm}$ ). The molar absorptivity coefficient $(\varepsilon)$ used for cyanidin-3-O-glucoside in a methanol solution was $26600 \mathrm{~L} \mathrm{~mol}^{-1} \mathrm{~cm}^{-1}$. Results were expressed as cyanidin-3-O-glucoside equivalents in milligrams per $100 \mathrm{~g}$ of fresh fruit (mg CGE $100 \mathrm{~g}^{-1} \mathrm{FF}$ ).

\section{Radical scavenging assays}

DPPH assay

Free DPPH (2,2-diphenyl-1-picrylhydrazyl) radical scavenging activity was assayed as previously described by Sánchez-Moreno et al. ${ }^{12}$ Briefly, $100 \mathrm{~mL}$ of five different concentrations of each sample was added to $3.9 \mathrm{~mL}$ of a methanol solution of DPPH $\left(60 \mu \mathrm{mol} \mathrm{L}^{-1}\right)$. After $60 \mathrm{~min}$, absorbance was measured at $515 \mathrm{~nm}$ (Lambda 25 UV-visible, PerkinElmer ${ }^{\circledR}$ ). Each sample was analyzed in triplicate, and the concentration of each extract that reduced $50 \%$ of DPPH concentration $\left(\mathrm{EC}_{50}\right.$ ) was expressed as $\mathrm{mg} \mathrm{mL}^{-1}$.

\section{ABTS assay}

Free ABTS (2,2'-azino-bis(3-ethylbenzothiazoline-6-sulfonic acid)) radical scavenging activity was assayed using the method previously described. ${ }^{13}$ Briefly, the ABTS radical was produced by mixing ABTS diammonium salt $\left(7 \mathrm{mmol} \mathrm{L}^{-1}\right)$ and potassium persulfate $\left(2.5 \mathrm{mmol} \mathrm{L}^{-1}\right)$. After $16 \mathrm{~h}$, the radical produced was diluted to produce a solution with an absorbance of 0.7 at $734 \mathrm{~nm}$. Finally, $10 \mu \mathrm{L}$ of five different concentrations of each sample was added to $1 \mathrm{~mL}$ ABTS radical solution. After $5 \mathrm{~min}$, absorbance was measured at 734 nm (Lambda 25 UV-visible, PerkinElmer ${ }^{\circledR}$ ). Each sample was analyzed in triplicate, and the concentration of each extract that reduced $50 \%$ of $\mathrm{ABTS}$ concentration $\left(\mathrm{EC}_{50}\right)$ was expressed as $\mathrm{mg}$ $\mathrm{mL}^{-1}$.

\section{Cytotoxicity screening}

Cytotoxic screening was conducted with three human cancer cell lines: A549 (non-small cell lung cancer cells, ATCC: CCL-185), RD (rhabdomyosarcoma, Instituto Adolfo Lutz, SP, Brazil) and DU145 (prostate carcinoma, DSMZ, ACC 261, Braunschweig, Germany). A549 and RD cells were cultivated in Eagle's minimum essential medium (MEM; Gibco, Carlsbad, CA, USA), and DU145 cells were grown in Dulbecco's modified Eagle's medium (DMEM; with high glucose and 1\% L-glutamine, Gibco). All cell lines were supplemented with $10 \%$ fetal bovine serum (FBS; Gibco) and maintained at $37^{\circ} \mathrm{C}$ and $5 \% \mathrm{CO}_{2}$ in a humidified atmosphere. Cytotoxic screening was performed by the sulforhodamine B (SRB) assay. ${ }^{14}$ Each cell line was exposed to different concentrations of the crude fruit extracts for $48 \mathrm{~h}$. Paclitaxel (Sigma-Aldrich) was used as positive control. The $50 \%$ cytotoxic concentration $\left(\mathrm{CC}_{50}\right)$ was defined as the concentration that reduced cell viability by $50 \%$ when compared to untreated controls, and was determined for each sample in triplicate.

\section{Antiherpes screening}

Two tests for determining anitherpes activity of fruit crude extracts were performed. First, the cytotoxicity of the extracts on Vero cells (ATCC: CCL81) was evaluated using the sulforhodamine B (SRB) assay as described above. These cells were grown in MEM supplemented with $10 \% \mathrm{FBS}$ at $37^{\circ} \mathrm{C}$ and $5 \% \mathrm{CO}_{2}$ for $24 \mathrm{~h}$, and exposed to different concentrations of the extracts for $48 \mathrm{~h}$. The 
$50 \%$ cytotoxic concentration $\left(\mathrm{CC}_{50}\right)$ of each sample was defined as the concentration that reduced Vero cell viability by $50 \%$ when compared to untreated controls. Second, the potential antiherpes (anti-HSV-1) activity was screened by plaque number reduction assay, as described previously. ${ }^{15}$ Vero cells were infected with approximately 100 PFU of HSV-1 (KOS strain - acyclovir sensitive; Faculty of Pharmacy, University of Rennes I, Rennes, France) for $1 \mathrm{~h}$ at $37^{\circ} \mathrm{C}$. The fruit extracts were added at non-cytotoxic concentrations after viral infection. Then, cells were washed with PBS, overlaid with MEM containing 5\% carboxymethylcellulose (Sigma-Aldrich) in the presence or absence of different concentrations of the fruit extracts and incubated for $48 \mathrm{~h}$. Cells were fixed and stained with naphthol blue-black (Sigma-Aldrich) and viral plaques were counted using a stereo microscope. The concentration of each extract that inhibited viral replication by $50 \%\left(\mathrm{IC}_{50}\right)$ when compared to untreated controls was determined. Acyclovir (ACV, Sigma-Aldrich) was used as positive control.

\section{Data analysis}

Statistical analyses were conducted using Graphpad Prism 6 software. An analysis of variance (ANOVA) was used to test differences among samples. Newman-Keuls multiple range test was used to verify differences. Pearson's correlation was used to determine whether there was a statistically significant relationship between two variables. Data are presented as means \pm standard deviations.

\section{RESULTS AND DISCUSSION}

\section{Anthocyanin identification}

The identification of anthocyanins was initially established by the presence of a characteristic absorption band at wavelengths ranging from 500 to $550 \mathrm{~nm}$ in the visible region of the electromagnetic spectrum. ${ }^{16}$ Identification of anthocyanins was based on tandem mass spectra and exact mass. Mass spectral data showed seven types of anthocyanins: those derived from pelargonidin $(\mathrm{m} / \mathrm{z} 271)$, cyanidin $(\mathrm{m} / \mathrm{z} 287)$, peonidin $(\mathrm{m} / \mathrm{z} 301)$, delphinidin $(\mathrm{m} / \mathrm{z}$ $303)$, petunidin ( $m / z 317)$, malvidin ( $/ \mathrm{z} 331)$ and carboxypyranpelargonidin ( $\mathrm{m} / \mathrm{z} 339)$. The sugar moiety was determined by tandem mass fragmentation spectra and by the elution order of anthocyanins. As previously described, glucose and galactose were the predominant sugars attached to the identified anthocyanins. ${ }^{17}$ To confirm identification, the exact mass and the spectra obtained were compared to those of MassBank ${ }^{\circledR}$ (https:// www.massbank.jp) and Metlin ${ }^{\circledR}$ (https://metlin.scripps.edu) databases. Twenty-one anthocyanins were detected in the fruits herein investigated, of which eight were detected for the first time in the respective species: delphinidin-O-galactoside, cyanidin-Ogalactoside, petunidin-O-galactoside, pelargonidin-3-Oglucoside, malvidin-O-galactoside, malvidin-O-pentoside and malvidin-O-acetylhexoside in pitanga fruits; and cyanidin-3-O-glucoside in araçá fruits.

Pitangueira is a native plant from Brazil that produces purple or red-colored fruit called pitanga. The LC/PDA/Q-TOF-MS of pitanga fruit showed 11 different anthocyanins (Table 1), and among these only cyanidin-O-glucoside (5), ${ }^{18,19}$ delphinidin-O-glucoside $(2)^{19}$ and one derivative of malvidin ${ }^{6}$ have been previously described for this fruit. Additionally, eight anthocyanins were identified in the red variety for the first time: delphinidinO-galactoside (1), cyanidin-O-galactoside pelargonidin-O-glucoside (10), petunidin-O-galactoside (11), pelargonidin-O-rutinoside (13), malvidin-O-galactoside (15),
malvidin-O-pentoside (20) and malvidin-O-acetylhexoside (21). Four anthocyanins were identified in the purple pitanga variety and two of them-cyanidin-O-glucoside (5) and delphinidin-O-glucoside (2) - had previously been described. ${ }^{18,19}$ The other two anthocyanins found - cyanidin-O-galactoside (3) and pelargonidin-O-glucoside (10) - were identified for first time in this variety.

In relation to araçá fruit, only one cyanidin derivative has been previously described. ${ }^{20}$ In the current study, only cyanidin-O-glucoside (5) was identified in both araçá varieties. To the best of our knowledge, this compound is described here for the first time.

Another berry analyzed in this study was blackberry - a species more widely cultivated than pitanga or araçá. The anthocyanin profile of blackberries has been widely described and encompasses 12 anthocyanin derivatives of cyanidin, peonidin, pelargonidin and malvidin. ${ }^{21}$ In the present study, four anthocyanins were identified in blackberry cultivar Tupy: cyanidin-O-galactoside (3), cyanidin-O-glucoside (5), cyanidin-O-rutinoside (7) and pelargonidin-O-glucoside (10), which is in agreement with previous reports for this fruit. ${ }^{21}$

Three strawberries cultivars (Camarosa, Aromas and Albion) were also investigated, and cyanidin-O-glycoside (5), pelargonidin-O-glucoside (10), pelargonidin-O-rutinoside (13) and carboxypyranopelargonidin-O-hexoside (18) were identified, which have been previously described in cultivars of Fragaria $\times$ ananassa. $^{22,23}$

Although the production of blueberries is more restricted to the Northern Hemisphere, the berries evaluated here were cultivated in southern Brazil. As previously described, ${ }^{24,25}$ blueberries presented the highest anthocyanin content in comparison to the other fruits examined here. As expected according to the LC/MS analyses, blueberries showed the highest anthocyanin complexity among all berry fruits herein investigated, with 15 anthocyanins identified: delphinidin-O-galactoside (1), delphinidin-O-glucoside (2), cyanidin-O-galactoside (3), delphinidin-O-pentoside (4), cyanidin-O-glucoside (5), petunidin-O-galactoside (6), petunidin-O-glucoside (8), cyanidin-O-pentoside (9), peonidin-Ogalactoside (11), petunidin-O-pentoside (12), peonidin-Oglucoside (14), malvidin-O-galactoside (15), malvidin-O-glucoside (16), peonidin-O-pentoside (19) and malvidin-O-pentoside (20). All compounds have been previously described in blueberry. ${ }^{24,25}$

Finally, it is important to emphasize that among all anthocyanins identified, only cyanidin-O-glucoside (5) was present in all nine berry extracts analyzed.

\section{Quantification of individual anthocyanins}

All anthocyanins identified in fruit extracts were also quantified individually by UPLC-PDA-ESI-MS. The methodology was validated according to ICH guidelines $(2005)^{26}$ using cyanidin-3-O-glucoside as an analytical standard, and the parameters evaluated were accuracy, precision, specificity, linearity, and limits of detection and quantification (Table 2). Among the fruits analyzed it was possible to determine the presence of one major anthocyanin in each fruit berry, with the exception of blueberry cultivar Bluegen.

Cyanidin-O-glucoside represented $45 \%$ and $80 \%$ of TAC in red and purple pitanga varieties, respectively (Table 3 ). In blackberries, cyanidin-O-galactoside represented more than $90 \%$ of TAC. All strawberry cultivars presented pelargonidin-O-glucoside as the predominant anthocyanin with $85 \%$ of TAC. Blueberry fruit showed the highest complex mixture of anthocyanins and the 
Table 1. Anthocyanins identified in nine berries evaluated

\begin{tabular}{|c|c|c|c|c|c|c|}
\hline Anthocyanin & $\begin{array}{l}\text { Retention } \\
\text { time (min) }\end{array}$ & $\lambda_{\max }(\mathrm{nm})$ & Molecular formula & $\begin{array}{c}{[\mathrm{M}]^{+} \mathrm{m} / \mathrm{z}} \\
\text { (error, ppm) }\end{array}$ & $\begin{array}{c}\text { Main } \\
\text { fragmentsm/z }\end{array}$ & Fruit berries \\
\hline (1) Delphinidin-O-galactoside & 6.17 & 507 & $\mathrm{C}_{21} \mathrm{H}_{21} \mathrm{O}_{12}^{+}$ & $465.1060(5.8)$ & 303 & $\begin{array}{l}\text { Red and purple pitanga; } \\
\text { blueberry }\end{array}$ \\
\hline (2) Delphinidin-O-glucoside & 6.69 & 507 & $\mathrm{C}_{21} \mathrm{H}_{21} \mathrm{O}_{12}{ }^{+}$ & $465.1060(5.8)$ & 303 & $\begin{array}{l}\text { Red and purple pitanga; } \\
\text { blueberry }\end{array}$ \\
\hline (3) Cyanidin-O-galactoside & 7.70 & 515 & $\mathrm{C}_{21} \mathrm{H}_{21} \mathrm{O}_{11}{ }^{+}$ & $449.1065(-4.2)$ & 287 & $\begin{array}{l}\text { Red and purple pitanga; } \\
\text { blackberry; Blueberry }\end{array}$ \\
\hline (4) Delphinidin-O-pentoside & 7.84 & 505 & $\mathrm{C}_{20} \mathrm{H}_{19} \mathrm{O}_{11}{ }^{+}$ & $435.0892(3.0)$ & 303 & Blueberry \\
\hline (5) Cyanidin-O-glucoside & 8.49 & 515 & $\mathrm{C}_{21} \mathrm{H}_{21} \mathrm{O}_{11}{ }^{+}$ & $449.1065(-4.2)$ & 287 & $\begin{array}{l}\text { Red and purple pitanga; } \\
\text { yellow and red Araçá; } \\
\text { strawberry cv. Albion, } \\
\text { Aromas and Camarosa; } \\
\text { blackberry, blueberry }\end{array}$ \\
\hline (6) Petunidin-O-galactoside & 8.95 & 522 & $\mathrm{C}_{22} \mathrm{H}_{23} \mathrm{O}_{12}^{+}$ & $479.1161(-6.1)$ & 317 & Blueberry, red pitanga \\
\hline (7) Cyanidin-O-rutinoside & 9.14 & 517 & $\mathrm{C}_{27} \mathrm{H}_{31} \mathrm{O}_{15}^{+}$ & $595.1705(7.1)$ & 449 & Blackberry \\
\hline (8) Petunidin-O-glucoside & 9.59 & 522 & $\mathrm{C}_{22} \mathrm{H}_{23} \mathrm{O}_{12}^{+}$ & $479.1161(1.1)$ & 317 & Blueberry \\
\hline (9) Cyanidin-O-pentoside & 9.64 & 517 & $\mathrm{C}_{20} \mathrm{H}_{19} \mathrm{O}_{10}^{+}$ & $419.0931(-4.7)$ & 287 & Blueberry \\
\hline (10) Pelargonidin-O-glucoside & 10.29 & 500 & $\mathrm{C}_{21} \mathrm{H}_{21} \mathrm{O}_{10}{ }^{+}$ & $433.1130(1.2)$ & 271 & $\begin{array}{l}\text { Red and purple Pitanga; } \\
\text { strawberry cv. Albion, } \\
\text { Aromas and } \\
\text { Camarosa; blackberry }\end{array}$ \\
\hline (11) Peonidin-O-galactoside & 10.86 & 517 & $\mathrm{C}_{22} \mathrm{H}_{23} \mathrm{O}_{11}^{+}$ & $463.1215(-5.4)$ & 301 & Blueberry \\
\hline (12) Petunidin-O-pentoside & 10.86 & 517 & $\mathrm{C}_{21} \mathrm{H}_{21} \mathrm{O}_{11}+$ & $449.1087(-0.1)$ & 317 & Blueberry \\
\hline (13) Pelargonidin-O-rutinoside & 11.09 & 500 & $\mathrm{C}_{27} \mathrm{H}_{31} \mathrm{O}_{14}{ }^{+}$ & $579.1721(1.2)$ & $433 ; 271$ & $\begin{array}{l}\text { Strawberry cv. Albion, } \\
\text { Aromas and Camarosa }\end{array}$ \\
\hline (14) Peonidin-O-glucoside & 11.76 & 517 & $\mathrm{C}_{22} \mathrm{H}_{23} \mathrm{O}_{11}^{+}$ & $463.1215(-5.4)$ & 301 & Blueberry \\
\hline (15) Malvidin-O-galactoside & 11.88 & 530 & $\mathrm{C}_{23} \mathrm{H}_{25} \mathrm{O}_{12}^{+}$ & $493.1326(-4.1)$ & 331 & Red Pitanga; blueberry \\
\hline (16) Malvidin-O-glucoside & 12.69 & 530 & $\mathrm{C}_{23} \mathrm{H}_{25} \mathrm{O}_{12}^{+}$ & $493.1326(-4.1)$ & 331 & Blueberry \\
\hline $\begin{array}{l}\text { (17) Cyanidin-O- } \\
\text { malonylhexoside }\end{array}$ & 12.87 & 518 & $\mathrm{C}_{24} \mathrm{H}_{23} \mathrm{O}_{14}^{+}$ & $535.1062(-4.9)$ & $449 ; 287$ & Blackberry \\
\hline $\begin{array}{l}\text { (18) Carboxypyranpelargonidin- } \\
\text { O-hexoside }\end{array}$ & 13,00 & 495 & $\mathrm{C}_{24} \mathrm{H}_{21} \mathrm{O}_{12}{ }^{+}$ & $501.1014(-3.8)$ & 339 & $\begin{array}{l}\text { Strawberry cv. Albion, } \\
\text { Aromas and Camarosa }\end{array}$ \\
\hline (19) Peonidin-O-pentoside & 13.03 & 515 & $\mathrm{C}_{21} \mathrm{H}_{21} \mathrm{O}_{10}^{+}$ & $433.1101(-7.9)$ & 301 & Blueberry \\
\hline (20) Malvidin-O-pentoside & 14.22 & 522 & $\mathrm{C}_{22} \mathrm{H}_{23} \mathrm{O}_{11}^{+}$ & $463.1207(-7.1)$ & 331 & Red Pitanga; blueberry \\
\hline $\begin{array}{l}\text { (21) Malvidin-O- } \\
\text { acetylhexoside }\end{array}$ & 20.29 & 528 & $\mathrm{C}_{25} \mathrm{H}_{27} \mathrm{O}_{13}{ }^{+}$ & $535.1425(-5.0)$ & 331 & Red Pitanga \\
\hline
\end{tabular}

Table 2. Parameters of the validated analytical methods for high-performance liquid chromatography detected by mass spectrometry for quantification of all anthocyanins expressed in cyanidin-3-O-glucoside

\begin{tabular}{|c|c|c|c|c|c|c|c|c|}
\hline \multirow[b]{2}{*}{ Compound } & \multicolumn{3}{|c|}{ Precision } & \multicolumn{2}{|c|}{ Accuracy } & \multirow{2}{*}{\multicolumn{2}{|c|}{$\begin{array}{c}\text { LOD } \\
\left(\mu \mathrm{g} \mathrm{mL}^{-1}\right)\end{array}$}} & \multirow[b]{2}{*}{$\begin{array}{c}\text { Linearity } \\
\left(R^{2}\right)\end{array}$} \\
\hline & $\begin{array}{c}\text { Concentration } \\
\left(\mu \mathrm{g} \mathrm{mL}^{-1}\right)\end{array}$ & $\begin{array}{c}\text { Repeatability } \\
\text { SDR(\%) }\end{array}$ & $\begin{array}{l}\text { Intermediate } \\
\text { precision } \\
\text { SDR(\%) }\end{array}$ & Mean(\%) & SDR(\%) & & & \\
\hline \multirow[t]{3}{*}{ Cyanidin-3-O-glucoside } & 0.04 & 5.5 & 5.0 & 105.0 & 4 & & 0.01 & \\
\hline & 3.12 & 3.5 & 3.8 & & & 0.02 & & 0.998 \\
\hline & 25.00 & 3.0 & 3.2 & & & & & \\
\hline
\end{tabular}

highest TAC, but they did not show one major anthocyanin compound.

\section{Total phenolic content (TPC)}

The TPC values of the evaluated berries are shown in Table 4. Among pitanga fruits, the purple variety showed a higher TPC (11 $400 \mathrm{mg} \mathrm{kg}^{-1}$ ) than the red one $\left(8280 \mathrm{mg} \mathrm{kg}^{-1}\right)$. Denardin et al. ${ }^{6}$ detected $7990 \mathrm{mg}$ TPC $\mathrm{kg}^{-1}$ fresh fruit for purple pitanga, while Filippi et al. ${ }^{27}$ detected $19810 \mathrm{mg} \mathrm{TPC} \mathrm{kg}^{-1}$ fresh fruit.

The strawberry cultivar Albion presented the lowest TPC when compared to the other cultivars evaluated. The TPC in all cultivars was higher than previously found in cultivar Camarosa (2600 mg GAE kg ${ }^{-1}$ fresh fruit), ${ }^{28}$ in cultivar Aromas $(2100 \mathrm{mg}$ GAE kg-1 fresh fruit), ${ }^{29}$ and in cultivar Albion (1700 mg GAE kg-1 fresh fruit). ${ }^{30}$ 


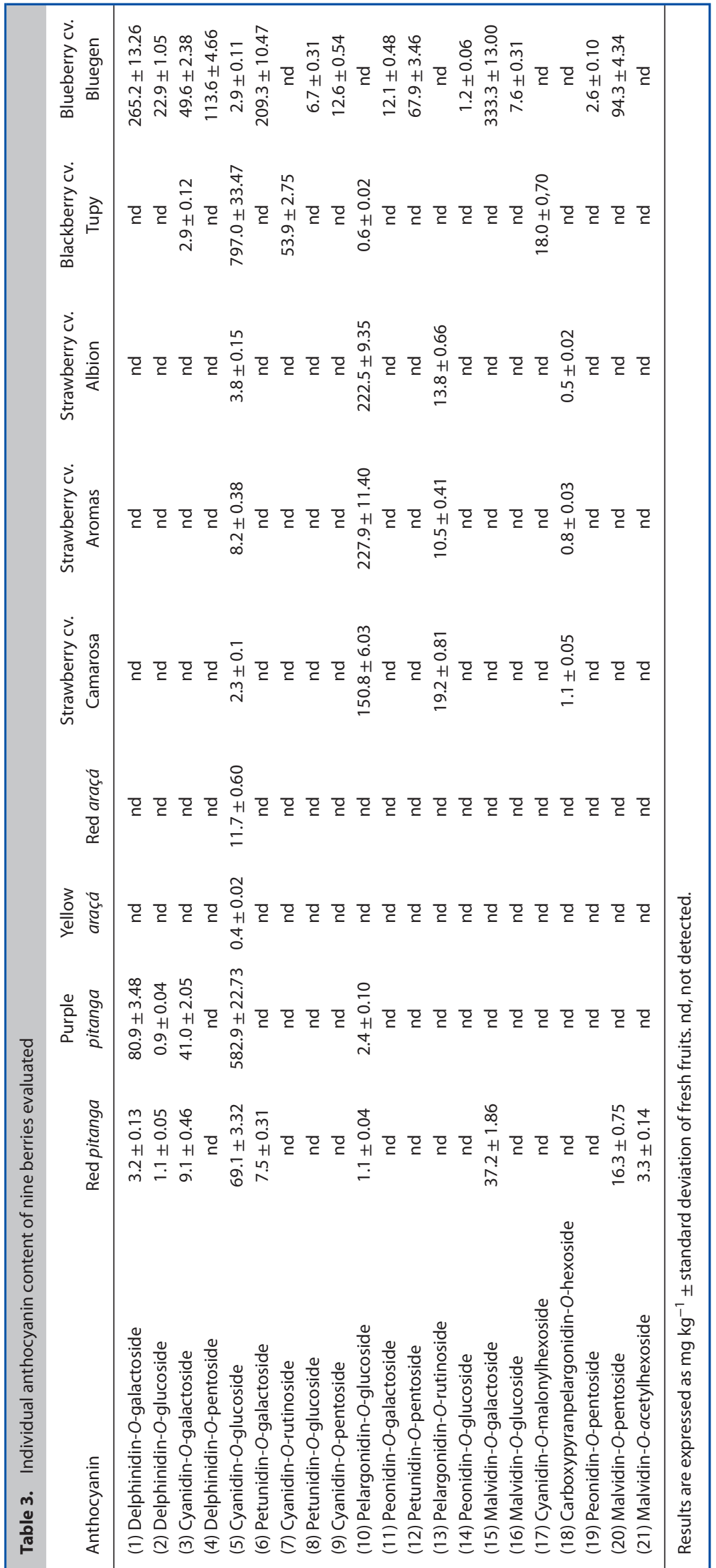




\begin{tabular}{|c|c|c|}
\hline & $\mathrm{TPC} \pm \mathrm{SD}$ & $\mathrm{TAC} \pm \mathrm{SD}$ \\
\hline Red pitanga & $8280 \pm 140 a$ & $14.8 \pm 2.2 \mathrm{a}$ \\
\hline Purple pitanga & $11400 \pm 120 b$ & $708.1 \pm 6.6 b$ \\
\hline Yellow araçá & $3820 \pm 120 c$ & $0.4 \pm 0.1 c$ \\
\hline Red araçá & $7190 \pm 150 d$ & $1.7 \pm 1.8 \mathrm{~d}$ \\
\hline Strawberry cv. Camarosa & $11660 \pm 200 b$ & $173.5 \pm 9.8 \mathrm{e}$ \\
\hline Strawberry cv. Aromas & $13550 \pm 230 e$ & $247.5 \pm 3.1 \mathrm{f}$ \\
\hline Strawberry cv. Albion & $10810 \pm 250 f$ & $240.7 \pm 3.2 f$ \\
\hline Blackberry cv. Tupy & $9210 \pm 60 \mathrm{~g}$ & $872.4 \pm 2.9 \mathrm{~g}$ \\
\hline Blueberry cv. Bluegen & $10900 \pm 250 f$ & $1202.0 \pm 7.6 \mathrm{~h}$ \\
\hline \multicolumn{3}{|c|}{$\begin{array}{l}\text { Data are expressed as } \mathrm{mg} \mathrm{kg}^{-1} \text { fresh fruit } \pm \text { standard deviation, } \\
\text { and represent the mean of three independent experiments. Dif- } \\
\text { ferent letters within each column indicate significant differences } \\
\text { (Newman-Keuls, } P \leq 0.05 \text { ). }\end{array}$} \\
\hline
\end{tabular}

The TPC values of araçá fruit were 7190 (red) and 3820 (yellow) $\mathrm{mg} \mathrm{kg}^{-1}$ fresh fruit. These results were slightly higher than those obtained by other authors, who detected TPC values ranging from 5370 to $7680 \mathrm{mg} \mathrm{kg}^{-1}$ fresh fruit. 6,31,32 Furthermore, blackberry and blueberry fruits showed TPC values of 9210 and $10900 \mathrm{mg} \mathrm{kg}^{-1}$ fresh fruit, respectively. In this study, purple Pitanga, all three cultivars of strawberries, and blueberries were the species with the highest TPC values. Although phenolic compounds in berries have been shown to present relevant antioxidant capacity by several mechanisms such as scavenging free radicals, chelating transition metals, inhibiting pro-oxidant and oxidant enzymes, and preventing lipid oxidation, they are not related to biological activities investigated herein.

\section{Total anthocyanin content (TAC)}

Purple pitanga fruit showed a higher TAC when compared to the red variety. Similarly, red araçá fruits presented a higher TAC than the yellow variety. Among the berries evaluated, blueberries (1200 $\mathrm{mg} \mathrm{kg}^{-1}$ ), blackberries (870 $\mathrm{mg} \mathrm{kg}^{-1}$ ) and purple pitanga (710 $\mathrm{mg} \mathrm{kg}^{-1}$ ) showed the highest TAC values (Table 4).

Anthocyanin contents of strawberry fruit cultivars Camarosa and Aromas were 170 and $250 \mathrm{mg} \mathrm{kg}^{-1}$ of fresh fruit, respectively, which are slightly lower than those obtained by other researchers. For instance, previous studies reported TACs of 260 and $300 \mathrm{mg} \mathrm{kg}^{-1}$ of fresh fruit, respectively, in cultivar Camarosa. ${ }^{35,36}$ Similar results were shown for cultivar Aromas, with a reported TAC of $2157 \mathrm{mg} \mathrm{kg}^{-1}$ fresh fruit. ${ }^{31}$ Many variables can explain the differences found among studies, including the distinct molar extinction coefficient values $(\varepsilon)$ used, which can range from 15600 to $31620 . .^{16}$ In this work, $\varepsilon=2600$ was used, which was calculated from our experimental data.

The completely conjugated structure of anthocyanins that allows electron delocalization results in very stable radical products, which is favorable when considering their antioxidant potential. Moreover, the degree and position of hydroxylation and methoxylation in the $B$ ring affect their stability and reactivity, and thereby also their antioxidant action. The results herein obtained using the DPPH assay are in accordance with previous observations on the effects of hydroxylation and methoxylation in the $B$ ring on the radical scavenging ability of anthocyanins. As previously described, the anthocyanidins lacking the O-diphenyl structure in the $B$ ring (malvidin, pelargonidin, petunidin and
Table 5. $\mathrm{EC}_{50}$ values $\left(\mathrm{mg} \mathrm{mL}^{-1}\right)$ of berries obtained from DPPH and $A B T S$ radical scavenging assays

\begin{tabular}{lcc} 
Berry & DPPH \pm SD & ABTS \pm SD \\
\hline Red pitanga & $52.02 \pm 0.47 \mathrm{a}$ & $125.70 \pm 3.85 \mathrm{a}$ \\
Purple pitanga & $17.76 \pm 0.27 \mathrm{~b}$ & $59.38 \pm 2.09 \mathrm{~b}$ \\
Yellow araçá & $49.26 \pm 0.79 \mathrm{c}$ & $91.94 \pm 1.02 \mathrm{c}$ \\
Red araçá & $60.11 \pm 2.36 \mathrm{~d}$ & $141.00 \pm 2.80 \mathrm{e}$ \\
Strawberry cv. Camarosa & $60.45 \pm 1.08 \mathrm{~d}$ & $95.96 \pm 5.99 \mathrm{~d}$ \\
Strawberry cv. Aromas & $65.06 \pm 0.30 \mathrm{e}$ & $114.10 \pm 2.72 \mathrm{~d}$ \\
Strawberry cv. Albion & $63.60 \pm 0.86 \mathrm{e}$ & $125.97 \pm 1.37 \mathrm{a}$ \\
Blackberry cv. Tupy & $16.84 \pm 0.50 \mathrm{~b}$ & $58.84 \pm 1.20 \mathrm{~b}$ \\
Blueberry cv. Bluegen & $9.82 \pm 0.48 \mathrm{f}$ & $49.97 \pm 5.11 \mathrm{f}$ \\
Gallic acid & $0.03 \pm 0.005 \mathrm{~g}$ & $0.03 \pm 0.004 \mathrm{~g}$
\end{tabular}

Data represent the mean of three independent experiments \pm standard deviation. Different letters within each column indicate significant differences (Newman-Keuls, $P \leq 0.05$ ).

peonidin) had lower scavenging efficiency toward the DPPH radical compared to cyanidin and delphinidin. ${ }^{35}$

\section{Radical scavenging assays}

Berries have been shown to possess important antioxidant activity. ${ }^{6,36,37}$ In this work, radical scavenging activity was measured by two standard assays (DPPH and ABTS). The results showed statistically significant differences among the fruit extracts analyzed concerning their antioxidant potential, which can be associated with their anthocyanin contents. The highest activity in both assays was found for blueberry fruit (Table 5). On the other hand, strawberries showed the lowest antioxidant potential among the fruits examined, with an $\mathrm{EC}_{50 \mathrm{DPPH}}$ value greater than $60 \mathrm{mg} \mathrm{mL}^{-1}$ for all cultivars.

According to data shown in Table 5, it can be noted that the radical scavenging potential of the samples was higher when obtained by the DPPH assay than by ABTS assay. However, the results obtained by different assays are not directly comparable due to the difference in the mechanism of radical capture occurring in each assay. ${ }^{12,13}$ Pearson correlation analyses for both assays and TAC showed a strong correlation $\left(r_{\mathrm{DPPH}}=0.86\right.$ and $\left.r_{\mathrm{ABTS}}=0.82\right)$ (Fig. 1), while TPC presented low negative correlations with the antioxidant potential of the samples $\left(r_{\mathrm{DPPH}}=-0.04\right.$ and $\left.r_{\mathrm{ABTS}}=-0.17\right)$.

Many studies have reported the relevant radical scavenging potential of berries. In one of these studies, Huang et al. ${ }^{37}$ showed high antioxidant activity for strawberry, blackberry and blueberry fruit using the DPPH and ABTS assays. Similar results were found for blackberry, araçá and pitanga fruit by the DPPH assay. ${ }^{6}$ Arend et al., ${ }^{36}$ however, reported a strong correlation $(r=0.97)$ between TAC of strawberry concentrates and their radical scavenging potential by DPPH assay. ${ }^{32}$

\section{Cytotoxicity against human cancer cell lines}

All dried berry methanolic extracts, when evaluated at the maximum concentration of $0.5 \mathrm{mg} \mathrm{mL}^{-1}$, were unable to reduce cell viability by $50 \%\left(\mathrm{CC}_{50}\right)$ in all tested cancer cell lines. These results corroborate those obtained by Elisia et al., ${ }^{38}$ who showed no cytotoxic effects for blackberry extracts $\left(0.1-10 \mathrm{mg} \mathrm{mL}^{-1}\right)$ against human cancer cell lines LNCaP, MCF7, and MDA-MB-453. ${ }^{38}$ In addition, Kulisic-Bilusic et al. ${ }^{39}$ also reported no cytotoxic effects for strawberry extracts $\left(0.5-2 \mathrm{mg} \mathrm{mL}^{-1}\right)$ against HT-29 cells. ${ }^{39}$ On 
TAC $\times$ DPPH

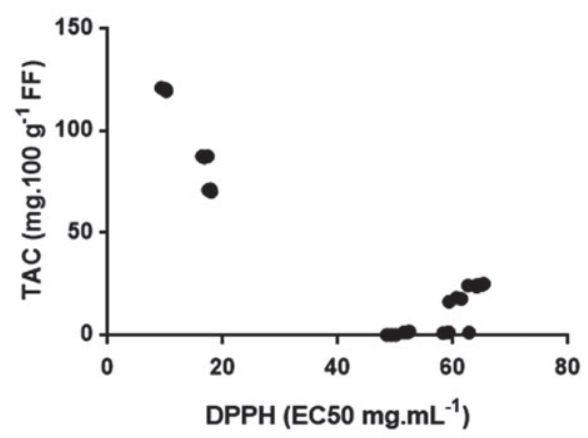

TPC x DPPH

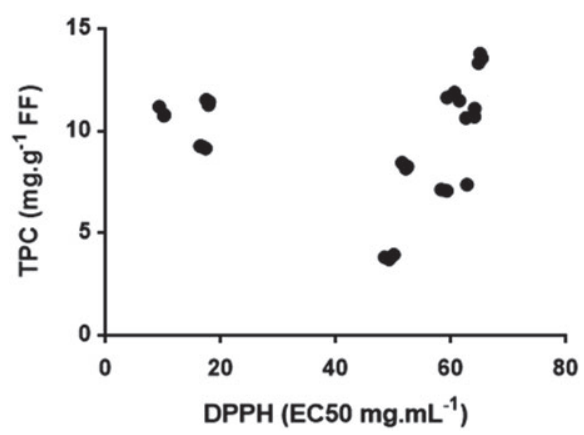

TAC $\times$ ABTS

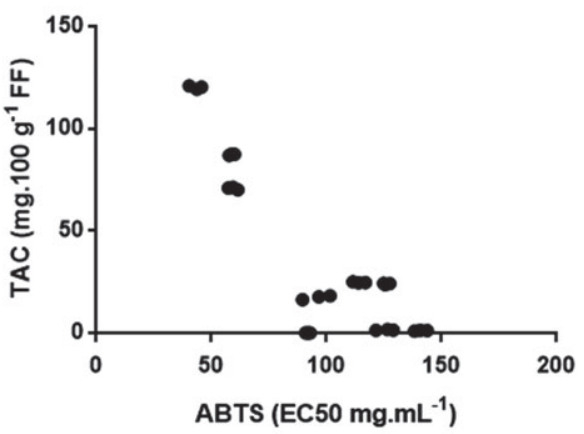

TPC $\times$ ABTS

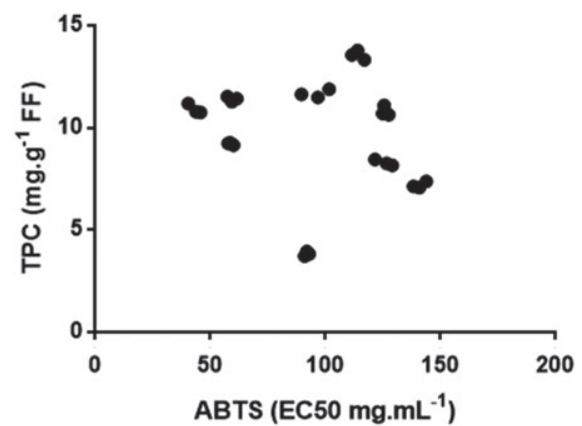

Figure 1. Pearson's correlation between TAC and TPC with DPPH and ABTS for nine berry extracts.

the other hand, Weaver et $a l .{ }^{40}$ showed cytotoxicity against cancer and normal human breast and prostate cell lines for a strawberry extract enriched in anthocyanins, and the maximum concentration tested was $10 \mu \mathrm{g} \mathrm{mL}^{-1}$, indicating that they were not selective.

\section{Antiherpes screening}

The evaluation of antiherpes activity (anti-HSV-1, KOS strain) was performed using the same concentration of methanolic dried berry extracts described previously. Similarly, no inhibition of viral replication by $50 \%\left(\mathrm{IC}_{50}\right)$ was observed for all tested samples. According to Cos et al., ${ }^{41}$ a concentration of $0.1 \mathrm{mg} \mathrm{mL}^{-1}$ should be the maximum concentration for plant extracts to obtain satisfactory antiviral activity. Therefore, the absence of inhibition of HSV-1 replication at $0.5 \mathrm{mg} \mathrm{mL}^{-1}$ indicates that the samples tested were not active under the experimental conditions of this study. While in a previous study inhibition of HSV-1 replication was observed with extracts of strawberry fruits, ${ }^{42}$ all samples tested in the present study were not active.

\section{CONCLUSION}

Anthocyanin profiles of several berries cultivated in southern Brazil varied according to species. Blueberries showed the highest total anthocyanin content and the highest complexity of anthocyanic compounds. For pitanga fruit, the presence of eight anthocyanins not previously described in this species was detected. Araçá fruit showed the lowest total anthocyanin content compared to the other berries tested, and cyanidin-O-glucoside was identified for the first time in this fruit. The total anthocyanin content of all tested fruits showed a strong positive correlation with free radical scavenging activity but not with total phenolic content, suggesting anthocyanins as the major contributor to the antioxidant potential of these berries. Finally, the in vitro evaluation of cytotoxicity against human cancer cell lines and antiherpes activity did not present promising results under the experimental conditions tested.

\section{ACKNOWLEDGEMENTS}

We acknowledge the Brazilian funding agencies CAPES (MEC) and $\mathrm{CNPq}$ (MCTI) for authors' research fellowships, and CNPq for financial support. The authors have no conflict of interest to declare.

\section{REFERENCES}

1 Del Rio D, Rodriguez-Mateos A, Spencer JPE, Tognolini M, Borges G and Crozier A, Dietary (poly)phenolics in human health: structures, bioavailability, and evidence of protective effects against chronic diseases. Antioxid Redox Signal 18:1818-1892 (2013).

2 Manganaris GA, Goulas V, Vicente AR and Terry LA, Berry antioxidants: small fruits providing large benefits. J Sci Food Agric 94:825-833 (2014).

3 Tsuda T, Dietary anthocyanin-rich plants: biochemical basis and recent progress in health benefits studies. Mol Nutr Food Res 56:159-170 (2012).

4 Liu C, Sun J, Lu Y and Bo Y, Effects of anthocyanin on serum lipids in dyslipidemia patients: a systematic review and meta-analysis. PLOS ONE 11:e0162089. doi:https://doi.org/10.1371/journal.pone .0162089 (2016).

5 Li Y, Zhang JJ, Xu DP, Zhou T, Zhou Y, Li S et al., Bioactivities and health benefits of wild fruits. Int J Mol Sci 17:E1258 (2016).

6 Denardin CC, Hirsch GE, Da Rocha RF, Vizzotto M, Henriques AT, Moreira JCF et al., Antioxidant capacity and bioactive compounds of four Brazilian native fruits. J Food Drug Anal 23:387-398 (2015).

7 Hussain I, Roberto SR, Fonseca ICB, De Assis AM, Koyama R and Antunes LEC, Phenology of Tupy and Xavante blackberries grown in a subtropical area. Sci Hortic 201:78-83 (2016). 
8 Moura GC, Vizzotto M, Picolotto L and Antunes LEC, Production, physico-chemical quality and bioactive compounds of misty blueberry fruit under different pruning intensities. Rev Bras Frutic 39:1-6 (2017).

9 Wang SY, Zheng W and Galletta GJ, Cultural system affects fruit quality and antioxidant capacity in strawberries. J Agric Food Chem 50:6534-6542 (2002).

10 Singleton VL, Orthofer R and Lamuela-Raventós RM, Analysis of total phenols and other oxidation substrates and antioxidants by means of Folin-Ciocalteu reagent. Methods Enzymol 299:152-178 (1999).

11 Lee J, Durst RW and Wrolstad RE, Determination of total monomeric anthocyanin pigment content of fruit juices, beverages, natural colorants, and wines by the $\mathrm{pH}$ differential method: collaborative study. J AOAC Int 88:1269-1278 (2005).

12 Sánchez-Moreno C, Larrauri JA and Saura-Calixto F, A procedure to measure the antiradical efficiency of polyphenols. J Sci Food Agric 76:270-276 (1998).

13 Re R, Pellegrini N, Proteggente A, Pannala A, Yang M and Rice-Evans $C$, Antioxidant activity applying an improved ABTS radical cation decolorization assay. Free Radic Biol Med 26:1231-1237 (1999).

14 Vichai V and Kirtikara K, Sulforhodamine B colorimetric assay for cytotoxicity screening. Nat Protoc 1:1112-1116.

15 Silva IT, Costa GM, Stoco PH, Schenkel EP, Reginatto FH and Simões $\mathrm{CMO}$, In vitro antiherpes effects of a C-glycosylflavonoid-enriched fraction of Cecropia glaziovii Sneth. Lett Appl Microbiol 51:143-148 (2010).

16 Giusti MM and Wrolstad RE, Characterization and measurement of anthocyanins by UV-visible spectroscopy, in Current Protocols in Food Analytical Chemistry, ed. by Giusti MM and Wrolstad RE. Wiley, Hoboken, NJ, pp. F1.2.1-F1.2.13 (2001).

17 De Pascual-Teresa S and Sanchez-Ballesta MT, Anthocyanins: from plant to health. Phytochem Rev 7:281-299 (2008).

18 Celli GB, Pereira-Netto AB and Beta T, Comparative analysis of total phenolic content, antioxidant activity, and flavonoids profile of fruits from two varieties of Brazilian cherry (Eugenia uniflora $\mathrm{L}$.) throughout the fruit developmental stages. Food Res Int 44:2442-2451 (2011).

19 Einbond LS, Reynertson KA, Luo XD, Basile MJ and Kennelly EJ, Anthocyanin antioxidants from edible fruits. Food Chem 84:23-28 (2004).

20 Biegelmeyer R, Andrade JMM, Aboy AL, Apel MA, Dresch RR, Marin $\mathrm{R}$ et al., Comparative analysis of the chemical composition and antioxidant activity of red (Psidium cattleianum) and yellow (Psidium cattleianum var. lucidum) strawberry guava fruit. J Food Sci 76:C991-996 (2011).

21 Seeram NP, Adams LS, Zhang Y, Lee R, Sand D, Scheuller HS et al., Blackberry, black raspberry, blueberry, cranberry, red raspberry, and strawberry extracts inhibit growth and stimulate apoptosis of human cancer cells in vitro. J Agric Food Chem 54:9329-9339 (2006).

22 Andersen $\varnothing \mathrm{M}$, Fossen $\mathrm{T}$, Torskangerpoll $\mathrm{K}$, Fossen $\mathrm{A}$ and Hauge $\mathrm{U}$, Anthocyanin from strawberry (Fragaria ananassa) with the novel aglycone, 5-carboxypyranopelargonidin. Phytochemistry 65:405-410 (2004).

23 Lopes-Da-Silva F, De Pascual-Teresa S, Rivas-Gonzalo J and Santos-Buelga C, Identification of anthocyanin pigments in strawberry (cv Camarosa) by LC using DAD and ESI-MS detection. Eur Food Res Technol 214:248-253 (2002).

24 He B, Zhang LL, Yue XY, Liang J, Jiang J, Gao XL and Yue PX, Optimization of ultrasound-assisted extraction of phenolic compounds and anthocyanins from blueberry (Vaccinium ashei) wine pomace. Food Chem 204:70-76 (2016).
25 Lohachoompol V, Mulholland M, Srzednicki G and Craske J, Determination of anthocyanins in various cultivars of highbush and rabbiteye blueberries. Food Chem 111:249-254 (2008).

$26 \mathrm{ICH}$ - Guideline HT, Validation of analytical procedures: text and methodology Q2 (R1), in International Conference on Harmonization, November (2005).

27 Filippi D, Bilibio D, Bender JP, Carniel N and Priamo WL, Kinetic extraction of total polyphenols from pitanga (Eugenia uniflora L.): effect of ultrasonic treatment, modeling and antioxidant potential. $J$ Food Process Eng 38:320-328 (2015).

28 Capocasa F, Scalzo J, Mezzetti B and Battino M, Combining quality and antioxidant attributes in the strawberry: the role of genotype. Food Chem 111:872-878 (2008).

29 Hernanz D, Recamales AF, Meléndez-Martínez AJ, González-Miret $\mathrm{ML}$ and Heredia FJ, Assessment of the differences in the phenolic composition of five strawberry cultivars (Fragaria $\times$ ananassa Duch.) grown in two different soilless systems. J Agric Food Chem 55:1846-1852 (2007).

30 Ornelas-Paz JDJ, Yahia EM, Ramírez-Bustamante N, Pérez-Martínez JD, Escalante-Minakata MDP, Ibarra-Junquera V et al., Physical attributes and chemical composition of organic strawberry fruit (Fragaria $\times$ ananassa Duch, Cv. Albion) at six stages of ripening. Food Chem 138:372-381 (2013).

31 Luximon-Ramma A, Bahorun T and Crozier A, Antioxidant actions and phenolic and vitamin $\mathrm{C}$ contents of common Mauritian exotic fruits. J Sci Food Agric 83:496-502 (2003).

32 Medina AL, Haas LIR, Chaves FC, Salvador M, Zambiazi RC, Da Silva WP et al., Araçá (Psidium cattleianum Sabine) fruit extracts with antioxidant and antimicrobial activities and antiproliferative effect on human cancer cells. Food Chem 128:916-922 (2011).

33 Amaro LF, Soares MT, Pinho C, Almeida IF, Pinho O and Ferreira IMPLVO, Processing and storage effects on anthocyanin composition and antioxidant activity of jams produced with Camarosa strawberry. Int J Food Sci Technol 48:2071-2077 (2013).

34 Cerezo AB, Cuevas E, Winterhalter P, Garcia-Parrilla MC and Troncoso $\mathrm{AM}$, Isolation, identification, and antioxidant activity of anthocyanin compounds in Camarosa strawberry. Food Chem 123:574-582 (2010).

35 Khknen MP and Heinonen M. Antioxidant activity of anthocyanins and their aglycons. J Agric Food Chem 51:628-633 (2003).

36 Arend GD, Adorno WT, Rezzadori K, Di Luccio M, Chaves VC, Reginatto FH et al., Concentration of phenolic compounds from strawberry (Fragaria $\times$ ananassa Duch) juice by nanofiltration membrane. J Food Eng 201:36-41 (2017).

37 Huang WY, Zhang HC, Liu WX and Li CY, Survey of antioxidant capacity and phenolic composition of blueberry, blackberry, and strawberry in Nanjing. J Zhejiang Univ Sci B 13:94-102 (2012).

38 Elisia I, Popovich DG, Hu C and Kitts DD, Evaluation of viability assays for anthocyanins in cultured cells. Phytochem Anal 19:479-486 (2008).

39 Kulisic-Bilusic T, Schnäbele K, Schmöller I, Dragovic-Uzelac V, Krisko A, Dejanovic B et al., Antioxidant activity versus cytotoxic and nuclear factor kappa B regulatory activities on HT-29 cells by natural fruit juices. Eur Food Res Technol 228:417-424 (2009).

40 Weaver J, Briscoe T, Hou M, Goodman C, Kata S, Ross H et al., Strawberry polyphenols are equally cytotoxic to tumourigenic and normal human breast and prostate cell lines. Int J Oncol 34:777-786 (2009).

$41 \operatorname{Cos}$ P, Vlietinck AJ, Berghe DV and Maes L, Anti-infective potential of natural products: how to develop a stronger in vitro 'proof-of-concept'. J Ethnopharmacol 106:290-302 (2006).

42 Carvalho A, Blum-Silva $\mathrm{CH}$, Calvete $\mathrm{E}$, Reginatto $\mathrm{FH}$ and Simões CMO, Anti HSV-1 activity of five strawberry cultivars. Lat Am J Pharm 31:133-137 (2012). 